\title{
Kim Il Sung, Idealogi Juche dan Pemerintahannya di Korea Utara
}

oleh

Noor Shuhana Zamhuri

\section{PENGENALAN}

Apabila menyebut tentang Korea Utara, tergambar sebuah negara yang terpencil, reclusive, miskin dan mempunyai ciri ciri politik warisan stalinism-komunism. Korea Utara seringkali dikembarkan dengan Kim Il Sung, presiden pertama Republik Demokrat Korea Utara (DPRK) yang merupakan pemimpin agung, mendapat gelaran suryong ${ }^{\prime}$ dan diiktiraf seperti raja-raja tradisional zaman klasik Korea. ${ }^{2}$ Boleh dikatakan dalam semua aspek kehidupan termasuk politik Korea Utara, imej Kim Il Sung mendapat trade mark. Beliau dianggap "model negara" dan merupakan "pemimpin yang paling dihormati dan dikasihi oleh empat puluh juta penduduk Korea Utara". Beliau seolah-olah menjadi icon sanjungan bagi masyarakat Korea Utara. Semua surat khabar, majalah, poster, ucapan, program radio, lagu, nama-nama tempat, buku dan lain lain lagi, secara langsung atau tidak merujuk kepada Kim Il Sung. Tempat kelahirannya dikatakan sebagai "buaian revolusi Korea" dan rumah di mana beliau dilahirkan diiktiraf sebagai tapak bersejarah. ${ }^{3}$ Beliau bukan sahaja menjadi "star" malah merupakan "sun of the nation". Sebenarnya tidak ramai yang tahu tabiat, hubungan peribadi ataupun personalitinya tetapi yang menariknya beliau telah 
danat menoubah negara sosialis Korea Utara. yang menerima pengaruh dan dominasi Soviet tinion ${ }^{-1}$ kepada pengaruh dan dominasi idealogi pribadinya sendiri. Kim Il Sung telah menerapkan cara pemerintahan yang berteraskan personaliti serta menganggap dirinỵa sebagai "pemimpin agung" untuk seluruh bangsa Korea. Makal Korea Utara terbentuk dengan gelaran DPRK. Ia mempunyai sistem politik yang tersendiri, terpisah dari politik Korea Selatan yang liberal dan banı̣ak menerima naungan Amerika Syarikat. Kim Il Sung membentuk Korea Ltara dengan mengagungkan diri dan keluarganya sebagai satu cara untuk menguatkan bangsa sendiri yang terpisah akibat campurtangan asing. ${ }^{5}$ Maka lahirlah idealogi Jucheism, hasil cantuman percaya kepada kebolehan dirisendiri yang disebatikan dengan ciri-ciri peribadi Kim Il Sung atau Kim Il Sungism. IdealogiJuche kemudiannya berkembang dalam politik, sistem ekonomi dan hampir keseluruhan perjalanan hidup individu Korea Utara. Ciri-ciri Kim Il Sungism dikaitkan dalam semua perkara sebagai penghormatan terhadap pemimpin mereka. Kim Il Sung dianggap great grandfather, maka anaknya, Kim Jong Il digelar great father. Kim Il Sung dan ahli keluarganya dianggap sebagai "patriotik" dan "revolusiner". Sepanjang hayatnya idealogi Jucbe mendapat tempat dan hampir seratus peratus masyarakat Korea Utara menvanjungnya. Bagaimanapun selepas kematiannya pada 1994, anaknya dijadualkan mengambil tempat sebagai presiden DPRK untuk meneruskan citacita dan idealogi politiknya. Tetapi mampukah Kim Jong Il berfungsi seperti Kim Il Sung? Artikel ini akan memberi penekanan kepada latar belakang peribadi Kim Il Sung yang merupakan teras kepada penubuhan DPRK, idealogi Juche dan personalitinya sebagai Presiden DPRK. Artikel ini juga akan membincangkan kredibiliti Kim Jong Il dan regim pemerintahannya. Apakah Korea Utara akan terus tenggelam dalam ketaksuban Kim Il Sung? Kenapa Kim Il Sung berjaya di Korea Utara akan disimpulkan oleh penulis di bahagian akhir.

\section{LATAR BELAKANG KIM IL SUNG}

Kim Il Sung dilahirkan di Mangyungdai, berdekatan bandar Pyongyang pada 15 April 1912. Beliau mendapat pendidikan awal di Sekolah Rendah Pertama Fusung pada tahun 1925. Nama asalnya dikatakan Kim Song Joo tetapi kemudiannya menukar nama kepada Kim Il Sung sempena nama salah seorang pejuang gerila Korea pada awal abad ke-20.6 Walaupun Kim II Sung dilahirkan dari keluarga yang miskin beliau dikatakan mempunyai latar belakang seorang pejuang. 
Keluarganya dikaitkan dengan semangat patriotism yang tinggi, terlihat dalam beberapa revolusi untuk memerdekakan Korea. Aỵhnỵa, ijm Hụung Jik, seorang pejuang Korea dalam angkatan menentang Jepun meninggal dunia pada tahun 1926 sewaktu beliau berusia 14 tahun." Kim Il Sung dan keluarganya berpindah ke Manchuria pada tahun 1920an sewaktu Perang Imin.

Di Manchuria beliau mendapat pendidikan di sekolah cina. ${ }^{8}$ Pada tahun 1927 beliau dilantik mengetuai Persatuan Pelajar Korea Ryugil (RAKSK). Pada usia 15 tahun beliau dipenjarakan oleh kerajaan China kerana terlibat dalam pembentukan Liga Pemuda Komunis (YCL). Selepas dibebaskan pada Mei 1930 beliau menubuhkan Tentera Revolusi Korea (KPRA) pada Mac 1934, yang merupakan gerakan gerila menentang tentera Jepun. Pada ketika itu beliau berusia 18 tahun dan bercita-cita ingin mengalahkan tentera Jepun. Beliau meninggalkan ibunya, Kang Ban Suk9 dan dua orang adiknya, Chul Joo dan Yung Joo untuk menjadi seorang tentera. Pada tahun 1931, beliau memasuki angkatan tentera gerila menentang Jepun di Manchuria yang secara tidak langsung menjadikan Kim salah seorang askar komunis Cina. Antara tahun 1932-41 beliau mengetuai gerila Korea menentang Jepun di Manchuria. Zaman pendudukan Jepun di Korea (1910-45) banyak memberikan latarbelakang kepada Kim Il Sung. Adiknya Chul Joo juga merupakan salah seorang pejuang antiJepun yang meninggal dunia pada usia 20 tahun. ${ }^{10}$ Ibunya pula meninggal dunia sewaktu beliau berusia 20 tahun. Apa yang pasti Kim Il Sung mengalami kehilangan ahli-ahli keluarganya sewaktu beliau masih muda. Ini semakin menguatkan semangatnya untuk terus berjuang membebaskan Korea dari cengkaman penjajahan. Beliau berkahwin sebanyak tiga kali. Isteri pertamanya Kim Chung Ae merupakan ibu kepada Kim Jong Il. Isteri keduanya iaitu Kim Chong Suk, merupakan seorang pejuang gerila dan yang paling disayanginya. Manakala isteri ketiganya, Kim Song Ae merupakan pengerusi Kesatuan Wanita Demokrat Korea Utara."

Pada tahun 1941, Kim meninggalkan Manchuria ke Soviet Union. Di sana beliau melibatkan diri dalam kumpulan revolusiner yang lain. Beliau banyak melancarkan kempen-kempen dan propaganda politik sehingga pulang semula ke Korea dalam pasukan askar Russia pada tahun 1945. Parti Buruh Korea (KWP) ditubuhkannya pada 28 Ogos 1946 yang merupakan parti bagi golongan yang bekerja, cantuman dari Parti Komunis Korea Utara dan Parti Demokrat Baru Korea. Kemudiannya beliau menubuhkan Parti Rakyat Korea Utara, sebagai kerajaan pertama untuk negara diktator proletarian Korea. ${ }^{12}$ Pada Februari 1947 
beliau dipilih sebagai pengerusinya. Pada 8 Februari 1948 beliau menyerapkan Askar Revolusi Rakyat Korea kepada Askar Rakyat Korea yang merupakan tulang belakang tentera Korea Utara. Pada kongres ke dua KWP yang diadakan pada Mac 1948, Kim Il Sung menetapkan dasar untuk kemerdekaan dan penyatuan negara dengan memperkuatkan asas-asas demokratik dan revolusiner bagi parti. Pada 9 September 1948 beliau menubuhkan DPRK dan menjadi kabinet kepada rakyat Korea Utara. Maka Kim Il Sung menjadi Presiden komunis dan ketua KWP.

Boleh dikatakan Kim Il Sung menerima pengaruh langsung dari Soviet sejak dari awal. Minat Soviet terhadap Korea Utara dan cita-cita Kim untuk membebaskan Korea dari pengaruh asing terutamanya Amerika telah membolehkan mereka bekerjasama. Beliau mengenepikan pelawaan BangsaBangsa Bersatu untuk hadir dalam pilihanraya Republik Korea Selatan pada tahun 1948 dan menganggap bekerjasama dengan Bangsa-Bangsa Bersatu sesuatu yang memalukan. Beliau juga mengharamkan Bangsa-Bangsa Bersatu hadir dalam pilihanraya Korea Utara pada tahun 1948.

Kim Il Sung juga merupakan pengerusi bahagian tentera DPRK dan Komander Askar Rakyat Korea yang berpengaruh. Hubungan baik dengan pihak Soviet menjadikan Kim Il Sung pemerintah yang diiktiraf oleh negara komunis. Maka cita-cita untuk menyatukan negara serta mengkomuniskan seluruh bangsa Korea telah mendapat perhatian dari pihak Soviet. Secara langsung dan tidak, dengan bantuan dan sokongan Soviet, Kim Il Sung telah melancarkan angkatan bersenjata menyeberang garisan 38 darjah garis lintang ke selatan sekaligus mencetuskan peristiwa Perang Korea yang merupakan satu trajedi untuk bangsa Korea. Ia bermula pada 25 Jun 1950 dan berakhir pada 27 Julai 1953. Maka peristiwa ini telah memisahkan satu bangsa kepada dua idealogi dan politik yang bertentangan sehingga hari ini. Perasaan marah, geram dan permusuhan telah menebal dalam diri rakyat Korea Selatan yang mempersalahkan Kim II Sung kerana melancarkan perang saudara dan membunuh saudara sendiri. Tidak hairanlah selepas terjadinya Perang Korea Kim Il Sung tidak popular bagi rakyat Korea Selatan. Ia dibenci, uicerca dan dikatakan pembunuh bangsa. Tetapi di Korea Utara beliau muncul sebagai hero, dan disanjung seperti dewa. Atas jasa dan pemerintahannya di dalam mengekalkan kemerdekaan Korea Utara, beliau telah dianugerahkan Marshal DPRK pada Februari 1953. Selepas perang, beliau membina semula ekonomi, meneruskan pemerintahan satu parti dan berjaya
membentukpersonality-cult di kalangan rakyat Korea Utara. Beliau mengambil 
Jucheism sebagai idealogi politik, iaitu cantuman idea Marxism dan komunism dan kemudiannya menerapkannya ke dalam sistem ekonomi dan masyarakat. Beliau merupakan pengerusi parti yang paling lama dan Setiausaha General bagi Parti Jawatankuasa Pusat; maka pada April 1992 beliau dianegerahkan gelaran Generalissimo oleh DPRK. Beliau juga telah dianugerahkan gelaran hero sebanyak tiga kali dan gelaran Hero Buruh DPRK serta beberapa anugerah lain.

Pada Julai 1994, beliau meninggal dunia di Pyongyang dalam usia 82 tahun. Kematiannya diratapi oleh jutaan rakyat Korea Utara. Semua golongan termasuk tua, muda, perempuan, kanak-kanak malah tentera juga turut bersedih dan meraung apabila mendapat berita kematiannya. Televisyen Korea Selatan merakam detik detik peristiwa pengebumian Kim dengan penuh kesedihan dan ratapan. Rakyat Korea Utara seolah-olah tidak dapat menerima berita kematian tersebut. Kanak-kanak tadika juga kelihatan menangis dan meratap seperti golongan tua dan dewasa. Ini jelas memperlihatkan kesedihan dan betapa sayangnya mereka kepada pemimpin mereka. ${ }^{13}$ Rakyat Korea Utara hanya mengenali seorang pemimpin sahaja iaitu Kim Il Sung dan kematiannya dianggap sesuatu kehilangan besar. Anaknya sendiri, Kim Jong Il yang sepatutnya menjadi pengganti beliau diragui berkebolehan untuk meneruskan perjuangan Kim Il Sung.

\section{DASAR DAN PEMERINTAHAN KIM IL SUNG}

Setelah negara Korea Utara terbentuk secara rasmi Kim Il Sung menjadi presiden DPRK yang pertama. Bagaimanapun terdapat rombakan kuasa sejak penubuhan Republik DPRK 1948 yang dicipta dan didominasi oleh Kim Il Sung sendiri. Beliau mahu menjadi ketua dari segi undang-undang yang sebenarnya, Perlembagaan baru dicipta untuk menyalurkan falsafahnya sebagai idealogi bagi masyarakat dan negara Korea Utara. Beliau telah menjadikan tradisi revolusi sebagai tradisi Korea, menubuhkan pejabat baru untuk presiden dan organ pentadbiran yang berkuasa pada Majlis Jawatankuasa Rakyat. Kim II Sung sebagai Presiden Republik, pengerusi majlis dan peranannya jelas dalam tentera sebagai komander dan pengerusi Jawatankuasa Pertahanan Negara.

Pada sidang mesyuarat plenary ke enam Jawatankuasa Pusat KWP pada Ogos 1953, beliau menetapkan ekonomi sosialis sebagai teras ekonomi negara dan memberi penumpuan kepada pertumbuhan industri berat. Industri ringan dan pertanian juga diberi perhatian terutama untuk kawasan luar bandar. Beliau 
memperkenalkan Plan Lima Tahun untuk pembangunan ekonomi negara pada kongres ke tiga KWP pada April 1956. Sejak itu Kim Il Sung mula memperkenalkan idea-idea sosialism dengan mencipta kaedah dan semangat Chongsanri (pengurusan sosialism) di dalam memperkenalkan idea-idea komunis dan pemerintahan rakyat yang berteraskan kepimpinan massa dalam KW. ${ }^{14}$ Beliau menjelaskan revolusi idealogi, teknikal dan pertanian akan berlaku dalam masyarakat sosialis setelah sistem sosialism terbentuk dan ini mesti diteruskan sehingga sistem komunism menjadi kenyataan.

Pada sidang kongres ke empat KWP yang diadakan pada September 1961 beliau memperkenalkan pula industri sosialism dengan melengkapkan semua sektor ekonomi negara dengan teknik-teknik moden dalam membangunkan negara industri sosialis. Ini jelas dalam Plan Ekonomi ke Tujuh phasa pertama di mana beliau mementingkan sektor pertanian. Sejajar dengan ini beliau memilih kawasan industri Elektrik Taean dan kawasan Sukchon, wilayah Pyongan pada Disember 1961 dengan memperkenalkan sistem kerja Taean yang merupakan sistem baru dalam pengurusan industri pertanian. Beliau juga memperkenakan idea dan teori untuk negara sosialis bagi membina kawasan luar bandar dengan idea-idea sosialis. Kim Il Sung yakin dengan ekonomi sosialis negara Korea Utara akan makmur dan dirinya akan berjaya sebagai pemimpin agung yang mementingkan satu parti dominasi rakyat.

Serentak dengan itu Kim juga memperkenalkan dasar tentera yang dapat membentuk satu cadre, dengan mententerakan rakyat dan memperkuatkan negara. Semua ini akan menjadi kenyataan seandainya dijadikan dasar negara; maka Kim Il Sung membentuk Perlembagaan Sosialis untuk DPRK yang dipersetujui dalam Perhimpunan Majlis Rakyat ke lima pada Disember 1972. ${ }^{15}$ Boleh dikatakan regim Kim tiada masalah dan beliau merubah perlembagaan pada tahun yang sama kepada pemerintahan berpusat yang lebih bercorak personnel yang dikuasai olehnya dan ahli keluarganya sahaja. Kim mahu rakyat setia kepadanya, kepada anaknya Kim Jong Il dan taatkan ibu bapa. Ini merupakan satu kelainan pada dasar pemerintahan negara sosialis di mana Kim Il Sung memfokuskan kepada diri dan keluarganya sahaja.

Kim mahu menjadi promoter untuk dirinya sebagai pemimpin di Korea Utara dan apabila berdepan dengan rakyat Korea Selatan. Beliau menggunakan parti untuk mendapatkan kuasa dan menubuhkan struktur kerajaan untuk memerintah negara berdasarkan pribadi daripada corak komunis. Beliau telah melanggar undang-undang dengan melebihi had tempuh perkhidmatan selama 
empat tahun sahaja tetapi tiada siapa yang berani mempersoalkannya. Malah seluruh rakyat Korea Utara termasuk Jawatankuasa Rakyat dan parti merasakan tiada siapa yang lebih layak dari Kim sendiri. Banyak perkara-perkara yang berkaitan dengan undang-undang dikaitkan dengan kuasa presiden dan presiden boleh membatalkan sesuatu. ${ }^{16}$ Maka kuasa Kim terus mutlak dan idealoginya menjadikan rakyat taksub kepadanya tanpa soal jawab.

...his every action is made to be heroic and his words or remarks automatically become law, with absolute power. ${ }^{17}$

Maka berkuasalah Kim Il Sung dengan caranya yang tersendiri di Korea Utara. Beliau cuba memberi kuasa kepada anak lelakinya iaitu Kim Jong Il sewaktu hayatnya lagi. Kim Il Sung memperkenalkan identitinya bagi rakyat Korea Utara sebagai diktator Jucheism. Rakyat pula menerima Kim sepenuhnya dan mengagungkannya. Mereka memakai lencana yang terdapat gambar Kim dan selepas beliau meninggal gambarnya digantikan dengan gambar anaknya, Jong Il. Lencana ini terdapat dalam berbagai bentuk, saiz dan warna. Rakyat asing tidak dibenarkan membeli lencana tersebut, hanya rakyat Korea Utara dan mereka yang menyanjung Kim Il Sung sahaja layak memakainya. Kanak-kanak sejak berusia tiga tahun lagi diajar menghormati dan membongkok di hadapan potrait Kim. Potrait Kim akan digantung di semua bangunan. Di bangunan tempat orang-orang Korea berkahwin juga terdapat potrait Kim. Maka pasangan yang berkahwin akan memberi hormat kepada Kim Il Sung selepas upacara penyembahan nenek moyang. Bersebelahan potraitnya adalah potrait Kim Jong Il, yang merupakan penggantinya yang telah dipropagandakan sejak tahun 1970an lagi. Banyak lagu-lagu yang dicipta untukgreat leader. Semua lagu-lagu tersebut bercorak propaganda yang mengagungkannya dan pemerintahannya. Kanak-kanak tadika disaran menyanyikan lagu "kita rakyat paling gembira sekali di dunia". Sebuah lagu dicipta khas, bertajuk song of marshal Kim Il Sung akan dinyanyikan sebelum lagu kebangsaan negara dimainkan.

Kim Il Sung mempunyai slogan politik iaitu "uisin chakch'uk" bermaksud membentuk diri dari contoh seseorang dalam karier politiknya. Stalin dan Lenin merupakan model peribadinya. Sosialism dan komunism merupakan teras politiknya. Tetapi apa yang berlaku di Korea Utara di bawah pimpinan Kim adalah suatu keadaan yang ganjil dalam politik diktator moden apabila beliau mengubahsuaikannya kepada politik mementingkan diri dan keluarganya. 
Beberapa tempat seperti universiti, cerita, bunga, sekolah telah meletakkan namanya.

Untuk mempastikan sebuah regim yang selamat dan terkawal, Kim Il Sung membahagikan rakyat DPRK kepada 51 katagori bagi memerhatikan kesetiaan mereka terhadap beliau. Terdapat tiga kelas yang rigid iaitu, kelas Teras, kelas Tak Stabil dan Seteru. Kelas Teras adalah mereka yang dikenalpasti kesetiaannya kepada Kim dan keluarganya. Kelas Tak Stabil adalah mereka yang seakan-akan menyokong Kim tetapi dikhuatiri menyebelahi politik dan idealogi Korea Selatan atau lain-lain. Manakala kelas Seteru adalah mereka yang dikenalpasti tidak setia kepada Kim dan merupakan anggota di dalam kem tahanan. Pengelasan masyarakat adalah berdasarkan latar belakang keluarga dan pekerjaan untuk mengenalpasti penyokong atau musuh politiknya. ${ }^{18}$ Untuk mengawal masyarakatnya Kim Il Sung memastikan mereka menganggotai organisasi sosial yang ditetapkan. Kanak-kanak lelaki wajib menganggotai kumpulan scout, pemuda dalam Liga Buruh Sosialis Pemuda, mereka yang bekerja dalam kumpulan Persatuan Kesatuan Sekerja, kaum wanita dalam Kesatuan Demokrat Wanita Korea, artis dalam persatuan sastera dan seni dan lain-lain lagi. Semua ini bertujuan memastikan masyarakatnya berorganisasi dan ini memudahkan beliau mengawal mereka atau memastikan kesetiaan mereka mengikut idealogi Kim Il Sungism.

Korea Selatan yang merupakan sebahagian dari Korea dianggap musuh kerana berlainan idealogi politik. Sejak pemisahan Korea, terdapat beberapa usaha yang cuba dijalankan oleh pihak Korea Selatan bagi menyelesaikan masalah penyatuan semula. Dasar ke Utara dijalankan bagi membolehkan ke dua-dua Korea berbincang masalah dan masa depan mereka. Dalam usaha-usaha penyatuan semula yang disaran oleh pihak Korea Selatan menerusi dialog Utara-Selatan Kim Il Sung menggariskan tiga prinsipal untuk penyatuan negara; iaitu kemerdekaan, keamanan penyatuan dan penyatuan bangsa Korea. Kim mahukan bangsa Korea ditadbir oleh bangsa Korea sendiri dan tidak mahu adanyz campurtangan asing apalagi peranan yang dimainkan oleh pihak Amerika Syarikat. Bagaimanapun pihak Korea Selatan masih memerlukan Amerika dan Amerika masih mempunyai markas tenteranya di Korea Selatan. Keadaan ini makin rencam apabila pihak Korea Selatan mahu usaha-usaha penyatuan dilakukan mengikut cara mereka manakala Kim Il Sung mahukan penyatuan berdasarkan Konfederasi Koryo. ${ }^{19}$ 
Berdasarkan konfederasi tersebut idealogi $/ u$ che merupakan idealogi utama yang perlu dikekalkan. Malah kedua-dua Korea perlu mentadbir bahagian sendiri dengan aliran politik masing-masing. Permintaan ini pasti tidak dipersetujui oleh pihak Korea Selatan yang mahu penyatuan dilakukan mengikut sistem liberal demokrasi. Pastinya pihak Korea Selatan tidak bersetuju dengan ekonomi atau masyarakat sosialis kerana ini semakin memecahkan masyarakat Korea. Ekonomi dan masyarakat sosialis merupakan cita-cita utama yang ingin dibentuk oleh Kim Il Sung maka usaha-usaha ke dua-dua Korea masih belum ada jalan penyelesaian. Bagaimanapun Kim Il Sung semakin memperkuatkan propaganda politiknya di Utara.

Pada Disember 1977 Kim Il Sung secara rasmi memperkenalkan ekonomi berorientasikan Jucheism dalam Plan Ekonomi ke Tujuh phasa ke dua antara tahun 1978-84. Maka semua aspek dalam pemerintahan Kim Il Sung dimobilisasikan mengikut idea sosialis berdasarkan kehendak Kim Il Sung sendiri. Dan Jucheism menjadi tema utama untuk memodelkan seluruh rakyat Korea Utara dalam revolusi Korea bagi membina ekonomi sosialis. Ini telah diterima sacara rasmi dalam kongres ke enam KWP pada Oktober 1980. Bagaimanapun beliau berhati-hati dalam hubungan luar. Politiknya tidak terbuka dan Korea Utara menjalankan dasar pintu tertutup. Pemerintahan DPRK hanya menjalankan idea dan kuasa mengikut kehendak Kim Il Sung sahaja.

\section{IDEALOGI JUCHE}

Kim Il Sung begitu kagum dengan idea-idea Stalin dan pernah menganggapnya sebagai god father sewaktu Stalin masih hidup. Maka idea Juche datangnya dari mereka yang mengkaji sosialism di Russia. Tetapi idea sosialism yang berada di Korea agak unik, seolah-olah menjadi Korean sosialism mengikut cara dan kuasa mutlak Kim Il Sung atau apa yang dikatakan monarcbial sosialism. Bagi rakyat Korea Selatan Jucbeism adalah idealogi rasmi Korea Utara untuk melengkapkan kediktatoran Kim II Sung. ${ }^{20}$ Juche bermaksud, "melakukan sesuatu dengan sendiri atau berdikari tanpa memerlukan pertolongan luar" bagi mengekalkan kemerdekaan negara. Dengan kata lain Jucbeism atau selfreliance bermaksud otonomi dalam kuasa politik, ekonomi dan sosial. Terasnya adalah sosialism dan Marxism ala-Soviet tetapi Kim Il Sung menjadikannya sebagai idealogi berkenaan dirinya atau Kim Il Sungism. 
Mengikut sarjana Korea, "Jucheism merupakan satu bentuk budaya dan kekuatan di kalasgan rakyat Korea Utara"." Boleh dikatakan idealogi Jucbe merupakan aspek utama di dalan memahami sistem nilai masyarakat Korea Utara, berdasarkan keadaan sebenar sosio-ekonomi dan maripulasi politik oleh Kim Il Sung.

Nasionalism merupakan komponen utama di dalam idealogi Juche. 0tang-orang Korea Utara sudah ditanam dengan semangat anti-jepun, kemudiannya seiepas berlakunya pemisahan Korea, digemburkan dengan semangat antiAmerika. Kim ll Sung yang mempunyai latar belakang pejuang anti-Jepun mulai mendapat tenpat dengan penerapan semangat anti-asing tersebut. Tidak mustahil Kim Il Sung menggunakan sentimen tersebut untuk membentuk cbarisma politiknya.

Jucheisme juga bernaksud man-centered di mana manusia membuat kepunusan untuk semua perkara, bebas, kreatif, bertanggungjawab dan menjadi master dalam masyarakatnya. Tetapi yang menjadi penimpin masyarakat adalah ketua, maka Kim II Sung berusaha membentuk dirinya menjadi pemimpin agung dan yang diagung-agungkan oleh rakyat. Rakyat wajib mentati pemimpin kerana dianggap penyelamat negara, malah budaya Konfucianisme menegaskan aspek loyalty kepada ketua di dalan melahirkan tanggungjawab filial fiety. Secara langsung atau tidakJucheism membentuk koleklivisme di kalangan masyarakal Korea Ltara selaras dengan kata-kata Kim Il Sung datam Perlembagaan Sosialis Korea Utara, arlikel 49;

Socialist life-style is in every particular collectivist life-styte. In the Democratic People's Republic of Korea, the right and obligation of the citizen is founded on such a collectivist principle as one for all, all for one. ${ }^{21}$

Jucbeism disemai dalam jiwa seluruh rakyal Korea Utara di semua peringkat. Bermula daiam sistem pendidikan; pelajar-pelajar sekolah diajar sejak tadika lagi untuk mentaati dan mengasihi ketua, yakni Kim Il Sung. Sesiapa yang menentangnya dihukum, dipenjara atau ditahan di kem-kem tahanan. Mereka 2kan diasingken dari keluarga dan masyarakat. Mereka yang disyaki menentang atau berfainan idealogi akan didenda, dipaksa berlapar, diterap dengan idealogis Kim Il Sungism yang bercorak revolusiner. Mereka ditempatkan dalann kawnsan yang tertutup, dibenarkan menanam jagung dan kentang untuk makanan harian mona bekalan ubat-ubatan. Wakaupun dalam keadaan sakit, mereka akan dipaksa 
bekejia 12 jam sehari seperti kerja-kerja melombong dan menambak tanah. Ramaj juga yang mati akubat kurang zat makanan dan penyakit dj dalam kem tahanan tanpa harapar untuk metarikan diri. Mereka yang melarikan diri akan ditembak serta merta. Dan bagl yang dapal ditangkap hidup-hidup akan dijadikan objek sasaran bagi latuhan menembak tentera. ${ }^{33}$

Maka secara langsung atau tidak rakyat korea Utara mesti patuh kepada pemimpin. Yatuh dan taat kepada pemimpin samada disebabkan oleh rasa takut, benci atau ciada pilihan menyebabkan idealogi Kim ll Sungism berkembang dan mengekalken Kim sebagai Presiden DPRK ldea menerapkan rasa sayang kepada pemimpin merupakan satu langkah terbaik untuk menyemaikan perasaan tersebut. Maka imej Kim Il Sung segar dalam ingałan rakyat. Media massa menceritakan prihal yang sama. Dilaporkan dalam suratkhabar enam halarnan Korea, nama Kim ll Sung disebut-sebut sebanyak 241 kali. ${ }^{24}$ Idealogi ini merupakan satu propaganda politik yang telah mengekaikan kuasa Kirn Il Sung di Korea Litara. Propaganda menupakan cara utama unzuk mententeramkan masyarakat dan menyenai perasaan tunduk mereka kepada kenıa negara. Rakyat mesti taat. Pemimpin dianggap agung, negara dianggap tempat terbaik untuk didudukj dan rakyat tidak tahu apa yang berlaku di dunia tuar. Sekatan dan hasutan menjadikan mereka takut. Tetapi ramai yang mesierima idealogi tersebut kerana telah disebatikan sejak mereka kecil lagi.

Berdasarkan idelogi/uche, hak-hak asasi manusia diketepikan sama sekali. Remaja tidak dibenar bercampur gaul. Mereka yang bercinta dianggap kurang bermoral dan usul perkahwinan periu mendapat persetujuan dari parti terlebih dahula. Lelaki di bawah urnur 30 dan perempuan di bawah umur 28 tidak di benarkan berkahwin kerana berkahwin awal dianggap akan nlengurangkan produktiviti buruh. Jika perernpuan berasal dari Pyongyang dan lelaki dari luar kota, maka pasangan tersebut tidak boleh tinggal di Pyongyang. Mereka tidak digalak berkahwin di luar kawasan mereka. Tiada kebebasan beragama dan sebarang lawalan dihadkan. Rakyal Korea Utara hidup sekadarnya bersesuaian dengan negara sosialis yang dibentuk. Mereki tidak mempunya kenderaan, matah tidak dibenarkan menaiki basikal. Mereka juga perłu mendapatkan permil perjałanan untuk ke tempat kerja. Mereka dibenarkan memiliki radio tetapi tidak dibenarken mendengar siaran asing. "s Kaum peremptsannya mempunyaj stail rambut yang sama manakala kaum lelaki memakai baju yang sama wama. Kanak-kanak perempuan di bawah umur 10 tahun diwajibkan memakai bunga yang djperbuat dari kain di kepala mereka dan kaum perempuan tidak akan 
berani berseluar panjang dan semua bangunan tidak mempunyai langsir. Terdapat kira-kira 40,000 Pusat Pengkajian Kim II Sungism di seluruh Korea Utara sam2da di kilang, pejabat, agensi awam, sekolah dan sebagainya. Pusat ini menyediakan poster, ucapan, hasil tulisan, buku, petz dan lain-lain yang berkenaan Kim dan perjuangan revolusinya. ${ }^{\text {* }}$

Idealogi Juche dikatakan diperkenalkan buat pertamakalinya oleh Hwang Jang Yop. ${ }^{27}$ Kenyataan ini dibuat berdasarkan keterangan yang dibuat olehmya pada 30 September 1966 dalam ulangtahun ke 20 Universiti Kim Il Sung tentang "ketaatan kepada Presiden dan Parti".

Loyalty to the Party and the President is the first life and glorious tradition of the University.'P

Idea ini diambil oleh KWP sebagai idealogi utama selaras dengan garis panduan parti berteraskan Marxism-Leninism. Kemudiannya Kim Jong Il mengembangkan idea ini apabila beliau mengambilalih tugas-tugas parti. Bagaimanapun Hwang Jang Yop dikenajpastj sebagai orang kuat dalam politik Korea Utara. Beliau lebih terkenal sebagai ahli politik dari professor universiti. Bagaimanapun selepas kematian Kim II Sung beliau mendapati ideologi Juche telah diselewengkan oleh mereka yang mahu mengekalkan kuasa di Korea Utara. Berita belizu melepaskan diri ke Korea Selatan merupakan satu kejutan besar bual seluruh rakyat Korea Utara dan Selatan. Nampaknya/ucheisme hanya bertahan sewaknu Kim It Sung masils hidup. Keadaan semakin buruk apabila Korea Utara mengatani masalah dalaman seperti bencana alam, kekurangan makanan, tidak kalibermya pengganti Kim Il Sung dan sebagainya.

\section{REGIM KIM JONG IL}

Kim Jong I merupakan anak lelaki Kim ll Sung yang sering disebut sebut sebagai pengantinya bagi memerintah Korea Utara. Beliau telah di lahirkan pada 16 Februari 1942 di Siberia dalam keluarga pejuang gerila. Beliau mendapal pendidikan awal antara September 1950 hingga 0gos 1960 di Jerman sebelum melanjutkan pelajaran ke Universiti Kim ll Sung dari September 1960 hingga March 1964." Beliau digelar suri yurri oleh Kim Il Sung dan merupakan successor design bagi DPRK. Beliau banyak menulis tentang idea-idea revolusi bapanya sewaktu berada di universiti teratama tentang/ucbeism dan masyaralkat sosialis. Jong il juga digelar party center bagi menunjukkan peri pentingn? 
imej beliau bagi rakyat Korea Utara. Sebenarnya latar peribadi Kim Jong It tidak jelas. Tetapi kebanyakan report menyatakan beliau tidak sekaliber bapanya dan banyak menghabiskan waktu dengan berpoya-poya. Disebabkan Kim II Sung mahu menyerahkan kuasa Korea Utara kepadanya Kim Jong Il telah diserapkan ke dalam kabinet parti secara langsung. Beliau dijadikan setiausaha KWP sejak Jun 1964 dan kemudiannya menjadi ahli Jawalankuasa Politik bagi Jawatankuasa Pusat pada Februari 1974. Beliau telah berusaha memperkuatkan parti dengan menerapkan sistem satu idealogi bagi masyarakat Korea Utara. Tugas beliau adalah mendidik ahli-ahli parti kepada idealogi Juche. Beliau kemudjantrya dipilih sebagai ahli dalam Biro Politik dan seliausaha bagi pertahanan Jawatankuasa Parti Pusal dalam persidangan kongres ke enam KWP yang diadakan pada Oktober 1980. Pada 1990 beliau menjadi Naib-Pengerusi bagi Jawatankuasa Pertahanan Negara DPRK dan komander askar Korea pada Disember 1991. Pada April 1992 beliau dianugerahkan Marshal DPRK. Beliau juga mendapat gelaran bero sebanyak dua kali dan Order of Kim Il Sung sebanyak tiga kali. Pada 9 September 1997 beliau ditantik secara rasmi sebagai Presiden DPRK selepas kira-kira tiga tahun Kim Il Sung meninggal dunia.

Selepas Kim Il Sung meninggal, rata-rata makyat Korea Utara merasakan kehilangannya. Pemimpin atasan parti terus mengingati beliau. Pejabat rasminya djadikan sebagai dewan peringatan. Mereka mengadakan parti hari lahir dan membuat slogan-slogan bagi memperingatinya. Njarannya iaiu Yubun terus dikekalkan dan Kim Jong Il pula cuba dijadikan model seperti Kim Il Sung dengan slogan-slogan berikut;

Comrade XIm II Sung is just the Comrade Kim Jong Il and Conrade Kim Jong Il is just the Comrade Kim Il Sung.

Bagaimarapun Kim Il Sung tetap KIm Il Sung dan Jong Il tidak seperti bapanya. Sejak kematian Kim II Sung, pihak tentera mendominasi pentadbiran DPRK.Kjm Jong ll didapatd tidak menunjukkan kebolehannya maka itulah sebabnya Perlantikannya sebagai presiden ditanggthkan selepas satu tahun berkabung. Bagaimanapun sarjana Korea, Prof Tae Hwan Kwak menyatakan penangguhan Perlantikan Jong Il adalah disebabkan keadaan ekononai." Pada ulangtahun hari lahirnya yang ke 50, 40 orang pemimpin alasan Pyongyang telah tidak hadir. Ini dilatakan dari peranan Jong II yang tidak menyakinkan..$^{92}$ Beliau 
dikatakon menghadapai masalah kesihatan. Pada Tahun Baru (1995) belian tidak muncul memberikan mesej thun baru sebaliknya menggantikan dalam bentuk editorial yang dibuat oleh pihak KWP. Desas desus mula kedengaran bahawa Jong Il tidak berkelayakan seperti bapanya. Dalam ulangtahunnya yang ke 55, Kim menyambutnya secara besar-besaran sehingka dikatakan "festise occasion for all human beings"s3. Parti ini bertujtuan untuk mengikiraf dirimya sebagai Pemimpin agung apabila berjuta-juta rakyat, dari parti buruh, kerajaan, petani, pegawai, lentera, dan lain-lainnya datang ke Pyongyang untuk menghantor "letters of loyalty" kepadanya. Parti ini dikatakan menelan belanja yang banyak Keadaan semakin tegang dengan bencana alam yng memusnahkan tanaman dan pertanian. Maka Korea Utara mengalani masalah kekurangan makanan sehingza mengakibatkan kebuluran. Bantuan luar terutamanya dari Bangon-Bangan Bersatu dan negara luar diminta membantu masalah kekurangan malonnan di Korea Utara.

Disebabkan masalah-masalah dalaman tersebut regim Kim Jong I dilihat gagal memberi keharmonian dan kesejahteraan kepada masyarakatuya Keadann semakin dahsyat apabila bilangan angka kematian meningkat dan ramai yang lari meninggalkan negara ke Korea Selatan, ke China atau ke Soviet Union. Korez Utara dilihat tidak selamat lagi untuk dihuni apabila tiada makanan. Slogan "pemimpin agung" tidak membantu apr-apa apabila perut kelaparn. Keadaan ini semakin membualkan keadaan di Korea Ltam tidak terkwwal. Hwang Jang Yop, salah seorang politikus kanan Kim Jong II , lari ke Korea Selaton empat hari sebelum "festive occasion" ulangtahun kelahiran Jong II. Keadan ini benar-benar memeranjatkan Korea Utara. Hwang menganggap masalhh kekurangan makanan membuatkan belizu berhijrah ke Korea Selatun via Beijing.

Kim Jong ll dianggap gagal membaiki masalah Korea Utarn sebaliknya banyak menghabis masa dan wang negara, Beliau juga terkenal sebagaj "ladies" man, heawy drinker with mental instability". ${ }^{4}$ Keadaan masa kecilnya yang bermasalah menjadikan beliau seorang yang tidak berkeyakinan. Regimnya tidak popular malah menjadikan idealogi $/$ uche dan DPRK terancam. Masalah dalaman Korea Utara semakin kronik dan rakyat mempersalahkan dasar kerajagn d2n pemimpin. Jong Il dianggap tidak patut menerajui DPRK Jong If tidak dapat menjadi pemimpin agung walaupun bapanya benar-benar dianggap penimpin agung. Imej Kim Il Sung tenus mekar dan mereka menganggap Kim II Sung stowsatunya Presiden di Korea Utara. Kim Il Sung mementingkan kewibawaan manakala Jong Il dibentuk menjadi pemimpin di bawah pusingan kuasa. Xison 1 
Sung lebih prihatin dengan masalah ekonomi dan cuba membentuk ekonomi sosialjsm manakala Jong Il lebih risau regimnya akan jatuh disebabkan masalah ekonomi yang melanda. Peranannya banyak ditampung oleh parti. Maka personaliti Kim Jong Il tidak layak dianggap great leader. Bagaimanapun pemimpin atasan terus menemuskan propaganda politik dengan menganggap Kim Jong Il seperti Kim Il Sung untuk mengelabui mata rakyal. Bagaimanapun rakyat Korea Utara mula sedar apa yang berlaku. Mereka pasti tiada perubahan yang akan dibuat maka mereka melarikan diri meninggalkan sanak saudara dan keluarga untuk mendapatkan hak asasi sendiri.

\section{KESIMPULAN: SEBAB-SEBAB KEJAYAAN KIM IL SUNG}

Boleh dikatakan Kim Il Sung berjaya membentuk dinasti di Korea Utara. Beliat muncul dengan imej yang diciptanya sendiri. Berlatarbelakangkan perjuangannya menentang kuasa asing beliau membentuk pemikiran rakyat Korea Utara agar membenci kuasa asing. Rakyat digembar gemburkan dengan propaganda bahawa apa yang ada di luar Korea Utara adalah buruk. Maka rakyat hanya mengenali dirinya sebagai pemimpin dan negara mereka sahaja. Maka penerapan idealogi Jucheism berjaya menyakinkan rakyat Korea Utara bahawa mereka mampu melakukan sesuatu perkara dengan usaha sendiri tanpa pertolongan orang lain. Maka idea Jucbe segar kekal dalam pemikiran rakyat dan penerapannya dalam semua aspek termasuk politik, ekonomi dan sosial terus mendapat tempat apabila rakyat sudah "dipropaganda dan dihasut". Maka penikiras rakyat sudah boleh menerima konsep pemimpin agung dan terus mengagungkan pemimpin mereka. Keadaan ini membantu menjayakan regim Kim untuk menegapkan diri dan kuasanya sebagai pemimpin komunis yang pating lana bertahan. Dasar-dasar Kim /l Sungism mengambil tempat dalam setiap aspek kehidupan masyarakat Korea Utara. Maka beliau menjadi sunong yang paling disayangi. Matah anaknya sendiri, Kim Jong Il gagal mengatasi bayangan Kim il Sung di Korea Ltara.

Kim beriaya membentuk DPRK kerana cita-cita politiknya untuk mengkomuniskan seluruh rakyat Korea dan mententerakan mereka. Negara jiran seperti China dan Soviet merupakan model terbampir yang membuatkan rakyal terus menerima dengan yakin. Dasar pengasingan yang tidak membenarkan mereka melihat atau mendengar siaran radio atau televisyen asing menyebabkan rakyat tidak berpeluang mengetahui apa yasg berlaku di dunia luar. Maka mereka harya tahu apa yang ada di negara sendiri sahraja. 
Regim Kim II Sung juga banyak melancarkan dasar propaganda dan hasutan. Slogan-slogan yang mengagungkan pemimpin dan menyatakan negara dan rakyat Korea Utara yang terbaik membuatkan rakyat terpedaya. Hasutan-hasutan memenjara dan memencilkan mereka yang berbeza idealogi menakukkan rakyat. Dasar kekerasan dan kurang kemanusiaan untuk mereka yang tinggal di kem. kem tahanan merupakan pengalaman yang ngeri. Idea-idea untuk mernencilkan masyarakaı dan pemikiran mereka semakin membualkan rakyat menerima membuta tuli keadaan yang ada di Korea Utara. Walaupun hisdup miskin dan susah tetapi propaganda yang dilaung-laungkan seolah-olah mereka adalah bangsa yang kaya dan harmoni, masyarakat yang terbaik dan rakyat yang paling gembira. Maka mahu atau tidak mereka harus mengikut dasar yang dipraktikkan. Dasar pemencilan, propaganda dan hasutan menjadikan rakyat terpengaruh dan tiada pilihan. Maka Kim Il Sung terus mendapat tempat dan penghormatan. Sebuah patung beliau berukuran 20 meter panjangnya dibina sebagaj lambang penting DPRK.

Rakyat DPRK dibentuk untuk menjadi negara dan masyarakat sosialis. Maka mereka bekerja keras beberapa jam seharl dikuti dengan kelas-kelas hasutan dan propaganda di waktu petangnya membuatkan rakyat terlalu penat untuk memikirkan perkara lain. Mereka tiada masa, peluang dan pendedahas menyebabkan dasar Kim II Sungism berjaya diserapkan.

Pendidikan idealogi diberikan sewaktu kanak-kanak lagi. Kanak-kanak dianggap penimpin di mass hadapan. Maka rakyat diajar ideal ogijucbe. Mereka menghadiri kelas, membaca slogan dan propaganda serta berbincang sesama mereka. Bagi golongan remaja dan dewasa mereka menghadiri kelas selepas masa kerja dan membaca tulisan-nulisan Kim it Sung. Mereka memprakktikkanmya atau mengkritkk sesama sendiri. Dengan cara ini Kim I Sung mengawal seluruh rakyatnya.

Walaupun pada peringkat awal Kim Il Sung merupakan boneka Soviet di dalam mendapatkan cita-citanya tetapi kebijaksanaan Kim untuk mengubahkannya kepada satu bentuk negara yang mengagungkan diri dan keluargaryza dalam regim komunis-sosialis menjadikan Korea Utara negara ciptann Kim II Sung. Imej Kim terus segar walaupun selepas beberapa tahun beliaut mendnggal dunia. Kim Jong II gagal menyakinkan rakyat Korea Utara. Beliau lebih suka mengasingkan diri dan pemerintahannya dilakukan oleh parti pusat. Masalah ketarangan makanan dan kebuluran semakin memburuknya imej beliav. 
Maka Korea Utara lebih sinonim dengan Kim Il Sung dan Kim Il Sung sememangnya "pemimpin agung" untuk masyarakatnya.

The Great Leader Marshall Kim Il Sung, a matchless patriot and a nation hero, crushed Japanese imperialism and returned triumphanty to the Ftherland. Ever since, he has devoted all his energies to the building of a new Korea... The truly great leader is the sun of the nation and a hero of construction who has created a new world for the people.". 
NOTA

1 Suryong bernaksud pemimpin agung. Kim Il Sung mengangap Lenin setangi "suryong kita" , Stalin sebagaj "suryong kitu yang dihormati" manakata Moa Tze Tung dianggap "suryong orang-orang Cina".

2 Sepert Raja Sukchong (1674-1720), Raja Yongju (1724-1*86) dan Raia Kojong (1863-1907).

3 M.P Srivastava, The Korean Confict: Searcb for Unification, Eastern Economy Edition, Taj Press, New Delht, 1982, hlm.8.

4 Korea Utara menjadi minat Soviet Union selepas tumatryz Perang Duniz ke II. Korea Ltara diperlukan sebagaj tempat persinggahan yang berdekomo dengan pelabuhan lau:nya di Vladivostok. Persaingan Soviet-Ametika di Asia Timur akhirnyya memisahkan Semenanjung Korea kepada dua bahagjan di garisan 38 darjah garislintang. Korea Utara djdominasi oleh Soviet linion dengan pengaruh komunism, idea-idea sulinism dan tentera

5 Dengan campurtangan asing seperti Amerika Syarikat, Soviet Union, Great Brithain dan China, isu Korea diperdebatkan dalam persidangan Yalta, Postidam dan Moscow. Secara langsung atau tidak Korea menjadi sandusicb kepada kasskuasa besar sehingga diletakkon dibzwah dasar brusteesbip selama 5 whun. Korez perlu berada dalam pengawasan kuasa-kuasa asing sebelum diberi kemerdekaan sebagai negara yang demokratik, bersans dan berkerajan sendiri. Korea dianggap sebagai negara yang paling crucial di Asia Timur maks Amerika bertanggungjawab mengamankas Smenanjung Korea selepas jepum meninggalkan Korea (1910-1945), Calude Buss, The United States and tbe Republic of Konea: Background for Policy, Hoover Instintion Press, Stanford, 1982, hlm 63.

6 "Kim II Sung", The Columbia Encyclopedia, edisi ke lima, Columbia Universily Press, 1993

7 Beliau dikatakan pernah menubuhkan Persanuan Kebangsaan Borez (NWW pada 1917 dan mengasaskan cbitwon bitu idez revolusioner anti-jepun.

8 "Kim II Sung", haps// violet.barkeley.edw korea/kimilsung.htuml.

9 Ibunyz dilahirkan pada 21 April 1892 di Chilgol, Ha-ri, wilaygh Pyungan selacan. Bapanya seorang pejuang den guru yang mengajar lebih 30 ahun. Ibuay. berkolwwin dengan bapanya pada 1908 sewaktu berusia 17 whun.

10 Baik Bong Kim II Sung (biograpby l), Dar Al-Talin, Beirut, Lebanon, 1973. him. 16

11 Xjm Chung te meninggal pada tahun 1949. Adik lelakj Jong Il meninggel dunia setahun sebelamnyz akibat lemas di Pyongyang. Kim Song Ae ingip meletakkan adik tirinya Xim Pyong sebaga pemimpin negara. Song fa 
merupakan salah seorang di kalangan keluarga yang ingin mencabar Kjm Jong Il.Peter Cromr, "The First Marxist Family Dynasty", General Anzeiger, West Germany, Oktober 14, 1980 (teriesnahan), dalam The Son Also Rises, The Institute for North Korea Studies, Seoul, Korea, hlm. 37.

12 Kim II Sung, A Brief Biograpby, Science and Encyclopedia Press Group, Pyongyang, Korea, 1993, hlm. 3.

13 Peristiwa ini dilihat sendiri oleh penulis yang kebetulan berada di Korea Selatan ketika itu. Kesedihan jelas kelihatan pada rakyat Korea Utara manakala sebahagian besar rakyat Korea Selatan bergembira kerana menganggap Kim II Sung pencetus kepada Perang Korea yang menisahkan mereka dan keluarga mereka Ada yang menjerit kegembiran. Manakala pihak kabinet Korea Selatan mengadakan mesyuarat tergembar berikutan berita kematian tersebut. Walaupun majoriti rakyat Korea Selatan membenci Kim Il Sung tetapi terdapat juga pengikut beliau dan golongan yang percayz kepada komunism berkabung atas kematiannya dan melakukan upacara sembahyang. Pelajar-pelajar universiti dilaporkan mengadakan pertimpunan dan berkabung. Ini didapati dari kesankesan upacara cbesa atau penyembahan nenek moyang.

14 Op cit, Kim II Sung: A Brief Biograpby, him.4.

15 Ibid,

16 Jawatankuasa Rakyat mempunyai kuasa seperti yang diperuntukkan dalam artikel 76 perlembagaan DPRK, perkara 8; "bahawa Jawatankuasa Rakyat (presidennya Kim Il Sung) berkuasa memilih dan memecal Presiden Mahkamah Pusat". Dalam artikel 142 menyatakan; "Mabkamah juga dikatakan berhubung dengan kuasa presiden" . Ini menperlihatkan peranan dan kuasa presiden adalah mutlak, Kim II Sung; Selected Works $V t$, Sovereign Languages Publishing House, Pyongyang, North Korea, 1995. hlm. 365.

17 Lim Un, The Founding of a Dynasty in Nortb Konea: As Aulbentic Btography of Kim Il Sung, Jhu-sha, Jepun, 1982, hlm. 156.

18 The Red Dymasty, The Institute of North Korean Studies, Seoul, South Korea, Jun 1982, hlm. 33-35.

19 Konfederas Koryo menggariskan beberapa prinsip seperti menjadkkan idealogi jucbe sebagai falsafah 252s, proses penyatuan berdasarkan penyempurnaan persekutuan dan menekankan pembangunan struktur negara bersalta. Kaum buruh menjadi penggerzk utama penyatuan. Persekutuan dua regara Korea dengan sistem dan pemerintahan masing-masing sebagaj bentuk Korea Bersatu. Lihat Dasear Ponyatuan, Pelayanan informasi Korea di Luar Negeri, Seowl, Kores, Nowember 1996. 
20 Kim Yong Kyu, "Value Systems of North Korean People", Vintage Point - Developments in Nortb Korea, wol. xix, no.7, Naewoe Press, Seoul, July 19\%, him. 31.

21 Jang Jae In, Political Idealogy of Nortb Konea: the fucbe Tbougbt, Instubule of Far Eastern Studies, Kyungnam University, Seoul, 1990, hlm. 229-230.

22 Op.cit "Value Systems of North Korean People", hlm. 35.

23 Op.cit, The Red Dynasty, film 32.

24 Ibjid, hlm. 68.

25 "Personality Gult Succession", Afterposten, Norway, September 4, 1980, (terjemahan) dalam Tbe Son Also Rises, him. 14.

26 op.cit, The Red Dynasty, hlm. 45

27 Hwang Jang Yop merupakan seorang pensyarah falsafah di Universiti Kim il Sung. Beliau mendapat pendidikan di Universiti Moscow. Hwang dikanakan tetlibat dalam politik Korea Utara dan menjawat beberapa jawalan utamz. Antaranya sebagai ahli jawatankuasa Pusat KWP (1970), Ketua Setiausahs Kommitte Pusat (1984), Naib-Pengerusi Agensi Keamanan dan Penyatuan Negara, Pengerusi Majlis Perhimpunan Rakyat, Pengerusi Diplomasj Asing dan sebagainya. Hwang Jang Yop merupakan orang kuat Kim II Sung tetapi lari ke Korea Selatan pada Februari 1997.

28 Hanlh Ho Suk, The Real Huang Jang Yop: An Analysis of Hwang lang Yop incident, Center for Korean Affairs, Inc, http://wrw kimsoft.com/korea/ whang.r.htm, bilm.3.

29 A Brief Biograpby of tbe Respected Leader Kim Jong II, bttp:ll wowpeocities, com/capitolHill/abby/l46//kimjongitbio.htm, him.3.

30 "Still Loyal to Late Kim's Teaching", Vantage Point: Developments in North Korea, vol.xix, no.7, Naewoe Press, Seoul, July 1996, him.2

31 Jong Il dikatakan tidak mahu membuat pengisytiharan pelantikan sewaktu rakyatnyz menderita kelaparan. Beliau juga dikatakan menunggu golongan pemimpin utama di DPRK yang berumur 70 atay 80 tahun bersara ataupum selepas mencapal kejayaan dalam hubungannya dengan Washington. Lihat "North Korea Has To and will Change Anyway", Vantage Point: Developments in Nortb Konea, vol.xix, no.7, July 1996, hlm. 12.

32 ibld, hlm. 4.

33 "Can Kim Jong II Tackle Serious Economic Troubles", Vantage Point: Datelopments in Nortb Korea, vol. xx, no.2, February 1997, hlm 1.

34 lbid, hlra.11.

35 op dt, Tbe Red Dynasty, hlm, 42. 
AIBUIOGRAFI

1 A Brief Biograpby of tbe Respected Leader Kim Jong /I, Science \& Encyclopediz Press Group, Pyongyang, Korea, 1993.

2 Baik Bong, Kim II Sung (biograpby I), Dar Al-Talia, Beirut, Lebaron, 1973.

3 Calude Buss, The United States and the Republic of Korea: Background for Policy, Hower Institution Press, Stanford, 1982.

4 "Can Kim Jong Il Tacke Serious Economic Trouble", Vantage Point: Developments in Nortb Korea, The Naewoe Press. Seoul, vol $x_{1}$, no.2, February 1997.

5 "Dasar Penyatuan", Pelayanon Infomasi Konea di Luar Kegeni, Seoul, Eorea, Nowember 1996.

6 Hahn Ho Suk, "The Real Hwang Jang Yop: An Anahssis of the Hwang Jang Yop

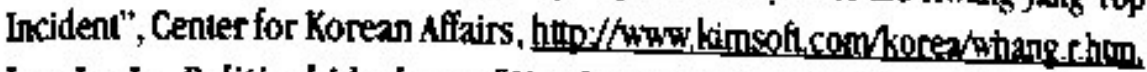

7 Jang Jae In, Political Ideology of Nortb Konera: The Juche Tbougbi, Inscitate of Far Eastern Sudies (IFES), Kyungnam University, Seoul, 1990.

8 "Kim Il Sung", The Columbia Encyclopedia, edisi ke lima, Colurabie University Press, 1993.

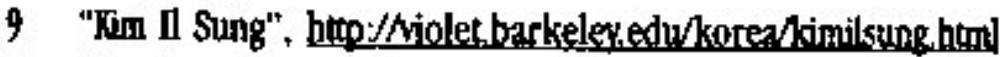

10 Rim /l Sung: Selected Forks $I V$, Sovereign Language Publishing House, Pyongyang, North Korea, 1995.

1I Kim II Sung: A Brief Biograpby, Science \& Encyclopedia Press Group, Pyongyng, North Korea, 1993.

12 Rim Sun Ryong, "The Juche Revolutionary Party", Ronsa Todoy, no.1, 19\%

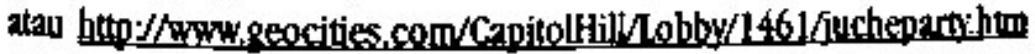

13 Kin Yong Kyu, "Value Systems of North Korean People", Vantage Point: Dexwopments in North Korea, Naewoe Press, Seoul, wol. xix no. 7, July 1997.

14 Lim Un, The Founding of a Biograpby, Science \& Encyclopedia Press Group. Pyongyang, North Korea, 1993.

IS H.P. Srivastiva, the Korean Conflict: Search for Inification, PRENICE Hall of India, New Delhi, June 1982.

16 "North Kore Has To and Will Change Anywry", (temuranah dengan Tae Horn Rwak), Vantage Point: Developments in Nortb Konea, val,xix, no. 7, July 1996.

17 Peter Crome, "Personality Cult Succession", Genenal Anzoiger, West Gernitny (terjemahan), September 4, 1980, dalam The Son Aloo Rises, The institule for Nonth Korea Studies, Seovil, Rore:

West Cermany 14 Okother 1980, dainn The Son Mloo Rises, The institule for North kores Studies, Seodi, Kone. 
19 "Soll Loyal to Iate Kim's Teaching", Vantage Point: Detelopment of Nonth Konea, The Naewoe Press, Seoul, vol. $x_{1} x_{+}$no. 7, July 1996.

20 The Red Dymasty, The Institute of North Korean Studies, Seoul, Toren, June 1982.

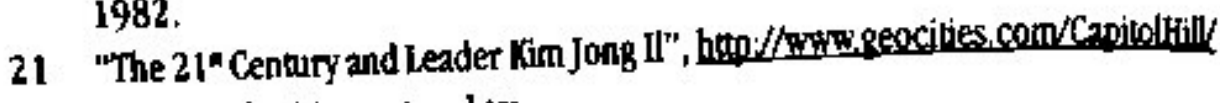
Lobb/1461/21stcenturyhtm

22 "The Great President's Life and Idealogy", hop/twrw geocities com/anitol lobby/1461/oreatoresidentitim 